\title{
ANALISIS GAYA KEPEMIMPINAN KEPALA SEKOLAH DALAM MENINGKATKAN KINERJA PENDIDIK SMK NEGERI 1 PALASAH KABUPATEN MAJALENGKA
}

\author{
Cucu Sunarti \\ Sekolah Menengah Kejuruan Negeri 1 Palasah, Kabupaten Majalengka, \\ Jawa Barat, Indonesia \\ Mahasiswa Pascasarjana, Universitas Majalengka \\ e-mail korespondensi : nocusun74@gmail.com
}

Disubmit Januari 2021, Diterima Maret 2021 , Diterbitkan April 2021

Submitted January 2021, Accepted March 2021, Published April 2021

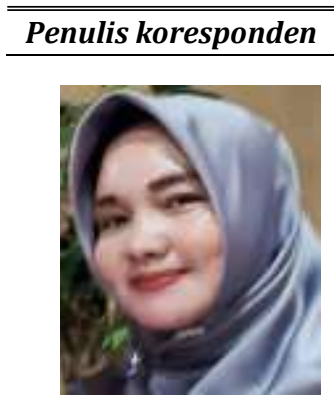

Jurnal DIALOGIKA

Manajemen dan Administrasi diterbitkan oleh Program Studi Administrasi Publik Pascarjana Universitas Majalengka

\begin{abstract}
The research aims to analyze and find out: a) the leadership style of the principal; b) The achievement of the principal in improving the performance of educators; c) Supporting factors and inhibiting leadership style; d) The efforts of the principal in overcoming obstacles. The study used a qualitative approach, techniques and primary data collection tools using in-depth interviews with selected informants purposively. Data were analyzed descriptively interpretive through data reduction, data presentation, and drawing conclusions. The validity of the data was tested through triangulation techniques. The results showed: a) The principal's leadership style is dominant in the type of coaching (training): b) The principal's achievements in improving the performance of educators include professionalism, creativity, discipline and awareness as well as interest in writing scientific papers; c) Supporting factors have some young and productive teachers, many opportunities for teachers to develop themselves. Inhibiting factors include limited costs, low interest of educators in writing scientific works, and technical barriers; d) The principal has done well in overcoming the obstacles he is facing. In conclusion, the leadership style of the principal is dominant in the type of coaching and is able to improve teacher performance.
\end{abstract}

Keywords: Leadership Style, Performance, Educator.

\begin{abstract}
Abstrak
Penelitian bertujuan untuk menganalisis dan mengetahui : a) Gaya kepemimpinan kepala sekolah; b) Capaian kepala sekolah dalam meningkatkan kinerja pendidik; c) Faktor pendukung dan penghambat gaya kepemimpinan; d) Upaya kepala sekolah dalam mengatasi hambatan. Penelitian menggunakan pendekatan kualitatif, teknik dan alat pengumpul data utama menggunakan wawancara mendalam terhadap informan yang dipilih secara purposive. Data dianalisis secara deskriptif interpretatif melalui reduksi data, penyajian data, dan penarikan kesimpulan. Keabsahan data diuji melalui teknik triangulasi. Hasil penelitian menunjukan : a) Gaya kepemimpinan kepala sekolah dominan pada jenis coaching (melatih: b) Capaian kepala sekolah dalam peningkatan kinerja pendidik meliputi profesionalisme, kreativitas, disiplin dan kesadaran serta minat menulis karya tulis ilmiah; c) Faktor pendukung memiliki sebagian guru muda dan produktif, banyak peluang bagi guru untuk mengembangkan diri. Faktor penghambat meliputi keterbatasan dana, rendahnya minat pendidik dalam menulis karya ilmiah, dan hambatan teknis; d) Kepala sekolah sudah berusaha dengan baik dalam mengatasi hambatan yang dihadapi. Kesimpulan, gaya kepemimpinan kepala sekolah dominan pada jenis coaching dan mampu meningkatkan kinerja pendidik.
\end{abstract}

Kata Kunci : Gaya Kepemimpinan, Kinerja, Pendidik. 


\section{PENDAHULUAN}

Masalah kinerja menjadi perhatian berbagai pihak, karena kinerja pemerintah akan dirasakan oleh masyarakat dan kinerja pendidik akan dirasakan oleh peserta didik dan orang siswa yang merupakan stakeholders utama pendidikan. Berbagai usaha telah dilakukan untuk mencapai kinerja yang baik untuk menghasilkan lulusan terbaik yang siap bersaing di era global yang semakin ketat. (Priangani,2013)

Dalam dunia pendidikan formal, kinerja pendidik merupakan faktor penentu keberhasilan pendidikan, namun untuk mewujudkannya diperlukan dukungan berbagai pihak, karena kinerja pendidik dipengaruhi banyak faktor baik internal maupun eksternal. Secara umum kinerja adalah melakukan suatu kegiatan dan menyempurnakannya sesuai dengan tanggungjawabnya dengan hasil yang memuaskan baik secara kualitas maupun kuantitas dalam rangka mencapai tujuan organisasi.(Widodo, 2005; Mangkunegara, 2007; Amelia, 2014). Salah satu tujuan organisasi lembaga pendidikan adalah memberikan layanan prima kepada stakeholders dalam bentuk layanan pendidikan melalui proses pmbelajaranyang bermutu sebagai wujud dari kinerja guru yang baik. Dengan demikian, antara kinerja dengan pelayanan merupakan duahal yang saling memperkuat. (Nurdiaman dan Rudiansyah, 2015). Untuk mewujudkan kinerja guru yang baik, dibutuhkan perhatian khusus terhadap faktor pembentuknya baik secara internal maupun eksternal.

Secara internal, kinerja guru dipengaruhi oleh kadar profesionalitas yang ditentukan oleh penguasaan terhadap empat kompetensi utama, yakni kompetensi pedagogik, kepribadian, sosial, dan profesional (UU No.14/2005). Secara spesifik dijelaskan pada lampiran Permendiknas Nomor 16 tahun 2007 tentang Standar Kualifikasi Akademik dan Standar Kompetensi Guru, bahwa "Standar kompetensi guru ini dikembangkan secara utuh dari empat kompetensi utama, yaitu kompetensi pedagogik, kepribadian, sosial, dan profesional. Keempat kompetensi tersebut terintegrasi dalam kinerja guru". Dengan demikian, secara internal kinerja guru ditentukan oleh penguasaan guru bersangkutan terhadap keempat kompetensi tersebut, bahkan untuk dapat dikatakan pendidik profesional seorangguru harus lulus uji kompetensi agar layak memperoleh sertifikat pendidik. Dengan kata lain, penguasaan kompetensi dapat menjadi faktor penentu kinerja yang baik. (Suhartini, 2014). Hal lain yang termasuk faktor internal antara lain motivasi, disiplin, tanggungjawab, dan komitment terhadap pelaksanaan tugas baik sebagai pengajar maupun pendidik.

Secara eksternal, kinerja guru ditentukan oleh lingkungan kerja, iklim organisasi, budaya sekolah, kemampuan manajerial dan kepemimpinan kepala sekolah. Dalam penelitian ini, difokuskan kepada faktor kepemimpinan kepalasekolah. Di mana dalam hal ini suatu lembaga pendidikan formal diperlukan adanya seorang pemimpin yang berkewajiban menentukan tujuan danmenggerakan semua warga sekolah untuk bersama-sama berperan dalam upaya mencapai tujuan pendidikan yang bermutu (Ulya, 2019). Oleh karena itu, kinerja guru secara individual akan terpengaruh oleh kinerja organisasi yang merupakan tanggungjawab kepala sekolah untuk mengelolanya. Dengan demikian,

kepemimpinan kepala sekolah ikut menentukan tinggi rendahnya kualitas pendidikan di sekolah bersangkutan diawali dengan mengelola dan menggerakkan sumber daya manusia, khususnya guru. Dalam penelitian ini, secara khusus difokuskan kepada gaya kepemimpinan kepala sekolah.

Secara formal, kepala sekolah dalam satuan pendidikan merupakan pemimpin tertinggi yang mempunyai dua peran penting dalam pelaksanaan proses pendidikan di sekolah. Pertama, kepala sekolah sebagai pendidik (fungsional), dan kedua, kepala sekolah sebagai pemimpin formal pendidikan (struktural). Kepala Sekolah bertanggungjawab atas manajemen 
pendidikan secara mikro, yang secara langsung berkaitan dengan proses pembelajaran. Artinya kepala sekolah berperan sebagai manajer untuk mehngelola semua sumber daya yang dimiliki sekolah.

Kaitannya dengan peran kepala sekolah sebagai manajer, Pidarta (2006:4) mengemukakan bahwa "Dalam pendidikan, manajemen itu dapat diartikan sebagai aktivitas memadukan sumber-sumber pendidikan agar terpusat dalam usaha mencapai tujuan pendidikan yang telah ditentukan sebelumnya". Dengan demikian nampak bahwa manajemen pada prinsipnya merupakan suatu bentuk penerapan manajemen dalam mengelola, mengatur dan mengalokasikan sumber daya yang terdapat dalam dunia pendidikan. Fungsi manajemen pendidikan merupakan alat untuk mengintegrasikan peranan seluruh sumberdaya guna tercapainya tujuan pendidikan dalam suatu konteks sosial tertentu, ini berarti bahwa bidang-bidang yang dikelola mempunyai kekhususan yang berbeda dari manajemen dalam bidang lain. Pandangan serupa dengan dengan fokusyang berbeda dikemukakan Murphy (2002), bahwa sekolah sebagai lembaga pendidikan mempunyai lima bentuk modal yang perlu dikelola untuk keberhasilan pendidikan yaitu : a) Integrative capital; b) Human capital; c) Financial capital; d) Social capital, and e) Political capital, dengan penjelasan singkat sebagai berikut.

Pandangan Murphy tersebut, dapat dijelaskan bahwa integratif adalah modal yang berkaitan dengan pengintegrasian empat modal lainnya untuk dapat dimanfaatkan bagi pencapaian program/ tujuan pendidikan; Modal manusia adalah sumber daya manusia yang kemampuan untuk menggunakan pengetahuan bagi kepentingan proses pendidikan dan pembelajaran; Modal keuangan adalah dana yang diperlukan untuk menjalankan dan memperbaiki proses pendidikan; Modal sosial adalah ikatan kepercayaan dan kebiasaan yang menggambarkan sekolah sebagai komunitas; dan Modal politik adalah dasar otoritas legal yang dimiliki untuk melakukan proses pendidikan dan pembelajaran. Kesemuanya itu dilakukan dalam rangka mencapai tujuan pendidikan yang telah ditetapkan.

Dengan demikian, nampak bahwa salah satu fungsi penting dari manajemen pendidikan adalah berkaitan dengan proses pembelajaran, yang berarti berkaitan dengan guru dan kinerjanya. Sekolah sebagai suatu lembaga pendidikan yang melakukan proses pembelajaran jelas perlu dikelola dengan sebaik-baiknya, hal ini berarti berkaitan dengan peran kepemimpinan kepala sekolah dalam memberdayakan kompetensi guru, lingkungan kerja, dan kinerja guru dalam upaya meningkatkan hasil pembelajaran yang baik.

Kemampuan kepala sekolah dalam memimpin pendidik dan tenaga kependidikan sangat berpengaruh terhadap terselenggaranya proses pendidikan dan pembelajaran dalam upaya mencapai tujuan yang diharapkan. Secara lebih spesifik, gaya kepemimpinan kepala sekolah erat sekali kaitannya dengan kinerja guru, terutama dalam membangun komitment dan tanggungjawab. Menurut Robbins (2010), "Pemimpin adalah seseorang yang mempengaruhi orang lain untuk mengikuti perintahnya dan memiliki otoritas manajerial. Sedangkan kepemimpinan adalah apa yang dilakukan pemimpin". Artinya, pemimpin adalah orangnya, sedangkan kepemimpinan adalah aktivitas seorang pemimpin dalam mempengaruhi orang lain sesuai dengan kewenangannya. Dalam penelitian ini, difokuskan kepada kepemimpinan kepala sekolah.

Pendapat lain tentang kepemimpinan dikemukakan Syamsudin, (2006) yang menyatakan bahwa "Kepemimpinan adalah kemampuan meyakinkan dan menggerakkan orang lain agar mau bekerja sama di bawah kepemimpinannya sebagai suatu tim untuk mencapai suatu tujuan tertentu. Kepemimpinan adalah bagian penting dari manajemen, tetapi tidak sama dengan manajemen". Dari pendapat ini, diperolh pemahaman bahwa

Secara teoretis, gaya kepemimpinan merupakan cara yang digunakan oleh pemimpin dalam mempengaruhi para 
pengikutnya. Dapat juga dikatakan bahwa gaya kepemimpinan merupakan norma perilaku yang digunakan seseorang pada saat orang tersebut mencoba mempengaruhi perilaku orang lain. (Mulyasa, 2003).

Dalam lembaga pendidikan formal, untuk dapat mempengaruhi orang lain (guru), diperlukan gaya kepemimpinan yang efektif, yaitu gaya yang mampu mempengaruhi, mendorong, mengarahkan, dan menggerakkan orang-orang yang dipimpin sesuai situasi dan kondisi dan bersedia melaksanakan tugas dengan semangat atas kesadaran sendiri (Yaqin, 2011). Dalam lingkup yang lebih luas, gaya kepemimpinan yang efektif adalah gaya kepemimpinan situasional berdasarkan tingkat kematangan bawahan, meliputi gaya telling, selling, participating, dan delegating (Robbins (2010), dengan penjelasan singkat : a) Telling (pekerjaan tinggi-relasi rendah), dalam model ini pemimpin menentukan peranan karyawan dan mengatur apa,kapan, bagaimana, dan di mana karyawan melaksanakan tugasnya; b) Selling (pekerjaan tinggi-relasi tinggi), pemimpin menunjukkan perilaku yang mengarahkan dan mendukung; c) Participating (pekerjaan rendah-relasi tinggi), pemimpin dan pengikutnya bersama-sama membuat keputusan, di mana pemimpin berperan sebagai fasilitator dan komunikator; dan d) Delegating (pekerjaan rendah-relasirendah), pemimpin kurang memberikan pengarahan atau dukungan.

Dari konsep tersebut, muncul empat model dari gaya kepemimpinan, yaitu: gaya kepemimpinan G1-Instruksi, yaitu jika direktif tinggi dan suportif rendah, gaya kepemimpinan G-2-Konsultasi, yaitu jika direktif tinggi dan suportif tinggi, gaya kepemimpinan G-3-Partisipasi, yaitu jika terjadi direktif rendah dan suportif tinggi dan gaya kepemimpinan G-4-Delegasi jika suportif rendah dan direktif rendah. Berikut gambar model pengelompokkan gaya kepemimpinan yang dikemukakan Hersey dan Blanchard dalam Robbins (2010),seperti pada gambar berikut ini:

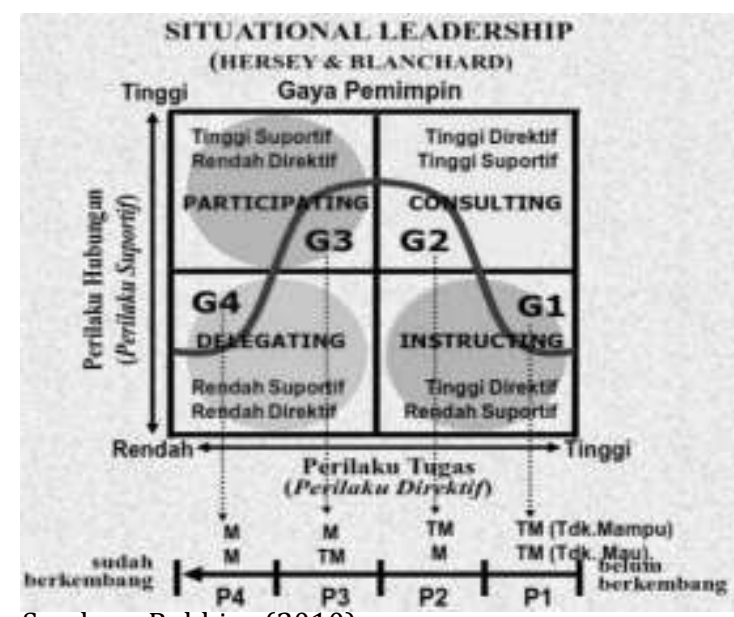

Sumber : Robbins (2010).

Gambar 1. Model Gaya Kepemimpinan

Jika dikaitkan dengan kepemimpinan kepala sekolah, maka secara natural gaya kepemimpinan kepala sekolah sangat bervariasi, tetapi belum banyak teori yang mengungkapnya. Oleh karena itu, untuk mengetahui jenis-jenis gaya kepemipinan yang memiliki indikator yang jelas perlu dipilih teori yang sudah baku sebagai pedoman. Berkaitan dengan gaya kepemimpinan seperti yang dikemukakn oleh Hersey dan Blancard tersebut, Permadi (2003:49) membaginya ke dalamempat jenis kelompok dasar gaya kepemimpinan yaitu :

a. Gaya mengarahkan (Directing). Pemimpin memberi petunjuk yang spesifik dan mengawasi secara ketat penyelesaian tugas.

b. Gaya melatih (Coaching). Pemimpin terus mengerahkan dan mengawasi secara ketat penyelesaian tugas, tetapi juga diikuti dengan menyelesaikan keputusan, sering meminta saran kepada bawahan, dan mendukung kemajuan.

c. Gaya mendukung, (supporting) pemimpin memberikan pasilitas dan mendukung usaha bawahan ke arah penyelesaian tugas dan membagi tanggung jawab, untuk membuat keputusan dengan para bawahan.

d. Gaya mendelegasikan, (delegating) pemimpin menyerahkan tanggung jawab kepada bawahan untuk mengambil keputusan.

Selanjutnya berkaiatan dengan penerapan atau aplikasi dari gaya kepemimpinan dimaksud tentunya masing 
mempunyai posisi di mana dan kapan diterapkannya secara tepat, karena tidak cukup suatu lembaga memiliki pemimpin yang kuat saja tapa dibarengai dengan penerapan gaya kepemimpinan yang tepat. Dalah hal ini, Permadi (2003:45) memberikan petunjuk tentang penerapan gaya ini bagi para kepala sekolah apabila mengadakan interaksi kedinasan dengan warganya sebagai berikut:

1) Gaya Directing, sesuai untuk diterapkan bagi orang-orang yang tidak kompeten tetapi bersemangat dan mempunyai komitmen, maka bawahan dalam kondisi demikian membutuhkan pengarahan dan pengawasan agar dapat mulai bekerja

2) Gaya Coaching, adalah sesuai untuk diterapkan bagi orang-orang yang cukup kompeten tetapi kurang mempunyai komitmen, maka bawahan dengan kondisi demikian membutuhkan pengarahan dan pengawasan karena belum mempunyai pengalaman

3) Gaya Supporting, adalah sesuai untuk diterapkan bagi orang-orang yang mempunyai kompetensi tetapi kurang rasa percaya diri dan motivasi. Maka bawahan dalam kondisi demikian tidak membutuhkan banyak pengarahan karena sudah terampil tetapi diperlukan untuk membina rasa percaya diri dan motivasi.

4) Gaya Delegating, adalah sesuai untjuk diterapkan bagi orang-orang yang mempunyai kompetensi dan komitmen tinggi mereka mampu dan bersedia bekerja sendiri dengan hanya sedikit pengawasan dan dukungan.

Namun demikian, dalam dunia pendidikan penerapan dari keempat gaya kepemimpinan tersebut, harus senantiasa disesuaikan dengan situasi dan kondisi di mana pemimpin itu bertugas. Selain itu, perlu juga menyesuaikan dengan karakter bawahan yang akan melaksanakan tugastugas yang diberikan pemimpinnya. Mengenai kepemimpinan kepala sekolah tidaklah cukup mempunyai keterampilam dan kemampuan dalam memimpin saja, melainkan perlu disertai dengan kemandirian. Kemandirian dimaksud adalah sikap dan prilaku kepala sekolah yang sanggup melakukan usaha-usaha kreatif dalam upaya memajukan sekolah yang dipimpinnya. Selain itu, harus sanggup juga mengadakan terobosan strategis dalam kondisi yang penuh tekanan, sehingga dapat membuka jalan atau menemukan solusi untuk memecahkan masalah yang dihadapi dengan cara-cara yang baik dan efektif.

Dari beberapa pendapat di atas dipahami bahwa yang dimaksud dengan gaya kepemimpinan kepala sekolah adalah sikap atau tingkah laku yang dilakukan kepala sekolah kepada bawahannya untuk mempengaruhi, menggerakkan dan mengarahkan agar bawahan bersedia dan dapat bekerja sesuai dengan kesepakatan bersama guna tercapainya tujuanpendidikan yang telah ditetapkansebelumnya.

Namun fenomena yang terjadi di lokasi penelitian, dari hasil observasi awal masih terlihat adanya kelemahan, antara lain kurang sinerginya antara sikap kepala sekolah dengan bawahannya, ditandai dengan rendahnya disiplin waktu, rendahnya kreativitas guru dalam pengembangan metode dan media pembelajaran, masih ada guru yang kurang menguasai materi ajar, dan rendahnya kesadaran untuk mengembangkan diri. Atas dasar hal tersebut, kepala sekolah dituntut untuk meningkatkan kemampuan yang memadai dalam mengambil inisiatif atau prakarsa, memiliki komitment dan motivasi yang kuat untuk meningkatkan kinerja guru yang akan berdampak pada peningkatan mutu pendidikan secara keseluruhan.

Berdasarkan kajian teori dankerangka penelitian, diajukan proposisi sebagai berikut:

1. Kepala sekolah dalam meningkatkan kinerja pendidik cenderung menggunakan gaya kepemimpinan coaching (melatih).

2. Capaian kepala sekolah dalam meningkatkan kinerja pendidik mencapai target dengan baik.

3. Terdapat faktor-faktor pendukung dan penghambat dalam meningkatkankinerja pendidik.

4. Dalam mengatasi hambatan yang dihadapi, Kepala Sekolah telahmelakukan berbagai upaya dengan baik. 


\section{METODE PENELITIAN}

Dalam suatu riset, penggunaan metode memegang peranan penting karena dengan adanya proses yang ditempuh memiliki arah dan acuan yang jelas. Adapun dalam penelitian ini, metode yang digunakanadalah penelitian kualitatif dengan pendekatan analisis deskriptif interpretatif. Penelitian berlokasi di SMK Negeri 1 Palasah, didasarkan atas fenomena yang ditemukan bahwa masih terdapat kelemahan dalam penerapan gaya kepemimpinan kepala sekolah, yang mengakibatkan rendahnya kinerja guru.

Untuk mengungkap fenomena tersebut dilakukan pengumpulan data dengan teknik wawancara mendalam, dilengkapi dengan teknik observasi dan dokumentasi. Wawancara dilakukan terhadap informan yang ditetapkan secara purposive, dalam arti memilih informan dengan kriteria tertentu yang diperkirakan paling memahami tentang topik yang diteliti,antara lain kepala sekolah, wakil kepala sekolah, pengurus komite sekolah, kepala tata usaha dan guru. Adapun banyaknya informan akan ditentukan dengan model snowball sampling, sehingga memungkinkan adanya penambahan informan sesuai dengan temuan di lapangan.

Substansi aspek wawancara ditetapkan berdasarkan teori yang melandasinya, yakni berkenaan dengan penerapan manajemen sekolah secara umum, gaya kepemimpinan kepala sekolah, dan kinerja guru. Data yang diperoleh diolah dan dianalisis melalui tahapan reduksi data, penyajian data, dan penarikan kesimpulan (Miles dan Huberman, 1992). Kemudian untuk menguji keabsahan data menggunakan teknik triangulasi, yakni memanfaatkan sesuatu yang lain di luar data untuk keperluan pengecekan sebagai pembanding (Moleong, 2005). Penelitian dilaksanakan pada tahun 2020.

\section{HASIL PENELITIAN DAN PEMBAHASAN}

Sesuai dengan rancangan penelitian kualitatif, di mana pengumpulan data dilakukan melalui teknik wawancara mendalam terhadap sejumlah informan terpilih, data yang diperoleh sangat banyak dan bervariasi. Maka untuk dapat menarik kesimpulan sesuai dengan propisisi yang diajukan, data tersebut diolah dan dianalisis melalui tahapan reduksi data, penyajian ata, dan penarikan kesimpulan. Kemudian, untuk menguji keabsahan data, dilakukan teknik triangulasi dengan membandingkan data yang diperoleh dengan sesuatu di luar data yang ada.

Dengan demikian, pemaparan hasil penelitian dan pembahasan menggunakan sistematika sesuai tahap analisis tersebut, yakni menyajikan simpulan hasil analisis, analisis pelaksanaan, dan pembahasan dari setiap proposisi yang diajukan.

Proposisi 1, Gaya Kepemimpinan Kepala Sekolah.

a. Simpulan

Dari hasil proses analisis diperoleh simpulan bahwa kepala sekolah cenderung menerapkan gaya kepemimpinan coaching (melatih). Tetapi, masih terdapat indikator yang menunjukkan perilaku gaya kepemimpinan supporting (mendukung) dan indikator gaya kepemimpinan delegating (mendelegasikan). Dengan demikian, perilaku gaya kepemimpinan kepala sekolah dapat dikatakan bervariasi, hanya saja lebih dominan dalam menerapkan gaya kepemimpinan coaching (melatih).

\section{b. Analisis}

Dengan memperhatikan simpulan tersebut, diketahui gaya kepemimpinan kepala sekolah lebih kuat menerapkan gaya kepemimpinan coaching (melatih). Gaya kepemimpinan ini cocok bagi para pendidik yang secara administratif profesional dan telah memenuhi standar yang ditetapkan, akan tetapi belum berpengalaman dalam pelaksanaan tugas di lembaga pendidikan yang memiliki dinamika yang khas, antara lain bekerja dalam satu tim. Dalam prakteknya, Kepala sekolah menerapkan gaya kepemimpinan coaching (melatih), karena banyak memperlihatkan perilaku kepemimpinan yang sejalan dengan teori yang dikemukakan Hersey dan Blancard dalam Robbins (2010), bahwa dalam menerapkan kepemimpinannya Kepala sekolah senantiasa memberikan pengarahan kepada para pendidik dalam melaksanakan tugas, baik melalui rapat awal tahun ajaran baru maupun rapat rutin 
bulanan dan pada saat melakukan brifing. Padahal secara administratif, sebagian pendidik telah mengetahui dan memahami job description masing-masing. Selain itu, pada saat bawahan melaksanakan tugasnya selalu diawasi secara ketat oleh kepala sekolah, sehingga kekurangan atau kekeliruan sekecil apa pun dapat dengan cepat diketahui dan kemudian dicarikan solusi untuk memecahkannya. Secara psikologis terdapat kelemahan, sebab pada mulanya para pendidik merasa tidak bebas karena selalu diawasi langsung oleh kepala sekolah. Tetapi bagi pendidik yang sudah terbiasa diawasi dan memaklumi gaya akan kepemimpinan kepala sekolah, justru berdampak positif karena dapat menciptakan suasana yang kondusif yang mendorong para pendidik untuk lebih taat dan patuh terhadap aturan yang berlaku. Selain itu, rasa kurang nyaman bagi sebagian pendidik karena ketatnyapengawasan lamakelamaan merasa tergantikan oleh dampak dari indikator gaya kepemimpinan coaching lainnya. Bahwa dalam hal menjalani proses pengambilan keputusan Kepala Sekolah senantiasa meminta saran kepada bawahan, sehingga jika dilihat dari tipologi kepemimpinan memperlihatkan tipe pemimpin demokratis yang banyak disukai oleh pendidik, bahkan dianggap tipe kepemimpinan terbaik. Penerapan gaya kepemimpinan coaching oleh kepalasekolah, berdampak pada kemajuan sekolah yang sangat baik. Dalam arti, sekolah mampu eksis dan menunjukkan prestasi yang membanggakan, baik para pendidik maupun peserta didik

\section{c. Pembahasan}

Kepala sekolah merupakan pemimpin yang bertanggungjawab untuk mengelola sekolah agar dapat menjalankan peran dan fungsinya sebagai lembaga pendidikan dalam menyelenggarakan pendidikan formal sesuai dengan peraturan perundangundangan yang berlaku dan dalam waktu yang sama dituntut juga untuk mampu mengimplementasikan visi-misi sekolah.

Secara administratif, kepala sekolah diangkat dan diberhentikan Pemerintah, oleh karena itu pertanggungjawaban kerja dilaporkan kepada instansi terkait. Dalam hal perseorangan (individu), perilaku gaya kepemimpinan kepala sekolah negeri terjadi perberbedaan karena dipengaruhi oleh faktor kepribadian dan karakter masing-masing. Fenomena yang ditemukan di lapangan menunjukkan bahwa secara individual terdapat perbedaan perilaku gaya kepemimpinan. Oleh karena itu, dalam penelitian ini fokus pembahasan diarahkan kepada jenis gaya kepemimpinan yang digunakan oleh para kepala sekolah. Dari hasil penelitian, diperoleh data bahwakepala sekolah memiliki kecenderungan terhadap perilaku gaya kepemimpinan yang bervariasi, namun lebih dominan pada gaya kepemimpinan coaching (melatih), ditandai dengan indikator-indikator gaya tersebut. Oleh karena itu, perilaku gaya kepemimpinan yang sering dijalankan oleh kepala sekolah adalah gaya kepemimpinan coaching (melatih). Selain itu dikatakan juga bervariasi, karena selain dominan pada gaya kepemimpinan coaching, untuk hal-hal tertentu melaksanakan juga perilakuperilaku yang memperlihatkan indikator gaya kepemimpinan supporting (mendukung) dan gaya kepemimpinan delegating (mendelegasikan).

Kuatnya perilaku gaya kepemimpinan coaching (melatih) bagi kepala sekolah sebagian dipengaruhi oleh beberapa hal, yaitu : a) Kepala sekolah memiliki tanggungjawab yang besar dalam menjaga eksistensi sekolah sebagai bentuk pelaksanaan tugas yang amanah sesuai dengan visi-misi sekolah; b) Kondisi saat ini, pada umumnya para pendidik dan tenaga kependidikan bertsatus PNS yang masuk kategori yunior, sehingga masihmemerlukan arahan dan bimbingan teknis karena kurang memadai dalam hal pengalaman kerja, sehingga walaupun standar kualifikasi ijasah telah terpenuhi tetapi hal-hal lain masih memerlukan binaan langsung dari kepala sekolah, terutama untuk membangun komitment agar mereka siap mengabdi sesuai dengan peraturan yang berlaku dan siap bekerja sebagai tim. Peran yang diperlihatkan oleh kepala sekolah ini merupakan penjabaran atau implementasi dari kompetensi kepala sekolah dalam mengelola guru (pendidik) dan staf dalam rangka pendayagunaan 
sumber daya manusia secara optimal (Permendiknas Nomor 13 tahun 2007); c) Dalam beberapa hal SMK Negeri 1 Palasah banyak mendapat bantuan dari pemerintah, tetapi dalam hal tertentu memerlukan juga bantuan dari masyarakat (orang tua siswa) yang dikoordinasikan dengan Komite Sekolah. Oleh karena itu, Kepala Sekolah banyak menggunakan gaya kepemimpinan coaching agar semua warga sekolah memiliki komitment dan loyalitas yang sama terhadap lembaga. Dalam upaya memajukan sekolah, kepala sekolah sering melakukan proses pengambilan keputusan secara bersama agar semua warga sekolah merasa ikut memiliki dan merasa bertanggung jawab untuk menjaga eksistensi dan memajukan sekolah secara bersama-sama.

Proposisi 2, Capaian kepala sekolah dalam meningkatkan kinerja pendidik.

a. Simpulan

Dari hasil proses analisis diperoleh simpulan bahwa dalam upaya meningkatkan kinerja pendidik, melalui gaya kepemimpinan coaching, kepala sekolah telah menunjukkan indikator ketercapaian sasaran, antara lain peningkatan profesionalisme ditandai dengan semakin meningkatnya penguasaan pendidik terhadap mata pelajaran (materi ajar), berkembangnya kreativitas pendidik ditandai dengan bertambahnya hasil karya pendidik berupa alat peraga, modul pembelajaran, dan innovasi pembelajaran. Secara psikologis, terdapat peningkatan disiplin dan kesadaran pendidik akan tanggungjawabnya sebagai pendidik profesional dan meningkatnya loyalitas. Dalam hal pengembangan diri melalui publikasi ilmiah, masih harus ditingkatkan lagi namun salah satu aspek dari pengembangan diri telah ada peningkatan, yakni dalam hal membuat karya ilmiah, antara lain menulis modul, membuat ringkasan materi pelajaran, dan menulis artikel untuk publikasi melalui media massa non-jurnal.

\section{b. Analisis}

Dengan memperhatikan simpulanhasil analisis, diketahui bahwa capaian kepala sekolah dalam meningkatkan kinerja pendidik cukup menggembirakan karena terdapat beberapa aspek peningkatan, terutama aspek profesionalisme. Penilaian kinerja pendidik merupakan bagian terpenting dalam manajemen pendidikan di lembaga pendidikan formal (sekolah). Khusus terkait manajemen sumber daya manusia, kepala sekolah memang memiliki kewenangan dan kewajiban untuk membina dan mengembangkan pendidik dalam segi kompetensi yang dalam prakteknya terintegrasi dalam dinamika kerja seharihari, sehingga akan erat kaitannya dengan gaya kepemimpinan yang diterapkan. Dari upaya yang dilakukan dalam meningkatkan kinerja pendidik, kepala sekolah mendorong, membimbing, mengarahkan, dan mengawasi pelaksanaan tugas yang dilakukan para pendidik terlihat adanya target yang telah tercapai, yakni : a) Peningkatan professionalisme pendidik, cerminan dari akumulasi kemampuan pendidik yang dibangun atas empat kompetensi utama, yakini kompetensi pedagogik, kompetensi kepribadian, kompetensi sosial, dan kompetensi profesional sesuai dengan amanat UU No 14 tahun 2005 tentang Guru dan Dosen yang secara operasional diperjelas oleh Permendiknas No. 16 tahun 2007 tentang Standar Kualifikasi Akademik dan Kompetensi Guru. Peningkatan profesionalisme pendidik ditandai dengan semakin meningkatnya penguasaan pendidik terhadap materi ajar sesuai dengan mata pelajaran yang diampu oleh masingmasing pendidik; b) Berkem- bangnya kreativitas pendidik; Kreativitaspendidik di sini dalam arti mampu mengolah materi pelajaran yang diampu secara kreatif sesuai dengan tingkat perkembangan peserta didik, kiemudian kreativitas pendidik diarahkan kepada pengembangan strategi dan teknik pembelajaran sebagai upaya agar peserta didik tertarik mempelajari materi yang disajikan dan mudah diserap oleh peserta didik. Implikasinya, peningkatan kreativitas pendidik ini ditandai dengan bertambahnya hasil karya pendidik berupa alat peraga, terciptanya aplikasi berbasis teknologi, dan tersusunnya modul pembelajaran, dan innovasi proses pembelajaran yang aktual; 
c) Terdapat peningkatan disiplin dan kesadaran terhadap tugas dan tanggungj awab sebagai pendidik profesional. Disiplin dan kesadaran ini masuk wilayah psikologis dan bersinergi dengan kompetensi pedagogik. Guru profesional dengan kematangan pada kompetensi pedagogik terlihat dari sikap dan perilaku sehari-hari tercermin dari kedisiplinan, loyalitas, tanggungjawab, sopan santun, peneladanan, dan berwibawa. Sikap dan perilaku seperti ini akan berkorelasi dengan kompetensi kepribadian dan kompetensi sosial yang pada akhirnya menyatu secara terpadu dalam diri pendidik profesional, karena keempat kompetensi tersebut merupakan satu kesatuan dalam diri pendidik profesional; d) Publikasi ilmiah; yaitu salah satu unsur yang menjadi bagian dari pengembangan keprofesionalan berkelanjutan bagi para pendidik. Kepala sekolah telah berusaha mendorong, membimbing, dan mengarahkan pendidik agar mengembangkan diri melalui publikasi ilmiah, namun hasilnya belum sesuai dengan harapan. Oleh karena itu, khusus tentang pembuatan karya ilmiah dan publikasinya masih harus ditingkatkan. Hal- hal yang telah tercapai baru sebatas membuat karya ilmiah, antara lain menulis modul,membuat ringkasan materi pelajaran, dan menulis artikel yang belum dipublikasikan.

\section{c. Pembahasan}

Secara yuridis dalam Permendiknas Nomor 13 Tahun 2007 tentang Standar Kepala Sekolah/Sekolah dijelaskan bahwa pada kompetensi manajerial terdapat kompetensi yang harus dimiliki oleh setiap kepala sekolah, yakni mengelola guru dan staf dalam rangka pendayagunaan sumber daya manusia yang ada di sekolah secara optimal. Dalam hal ini, kepala sekolah dengan semangat membina pendidik agar terjadi peningkatan dalam kinerja, merupakan langkah tepat dan telah sesuai dengan peran dan fungsinya sebagai kepala sekolah, lebih khusus berusaha mengelola guru agar kadar keprofesionalannya meningkat. Apabila merujuk kepada amanat Undang-undang Nomor 14 Tahun 2005 tentang Guru dan Dosen danPermendiknas Nomor 16 tahun 2007 tentang Standar Kualifikasi Akademik dan Kompetensi Guru, bahwa seorang pendidik profesional ditandai dengan penguasaan terhadap empat kompetensi utama, yakni kompetensi pedagogik, kompetensi kepribadian, kompetensi sosial, dan kompetensi profesional. Namun fakta di lapangan, masih terdapat pendidik profesional yang belum mampu memperlihatkan kompetensi yang diharapkan secara khusus, dalam arti belum setiap butir kompetensi terpenuhi dengan baik. Dalam Permendiknas No 16/2007, terdapat penjelasan tentang kompetensi inti guru dan kompetensi guru mata pelajaran, salah satu dari penjelasan tersebut berkaitan dengan kompetensi profesional, yaitu : (1) Menguasai materi, struktur, konsep, dan pola pikir keilmuan yang mendukung mata pelajaran yangdiampu; (2) Mengembangkan keprofes- sionalan secara berkelanjutan dengan melakukan tindakan reflektif; (3) Memanfaatkan teknologi informasi dan komunikasi untuk mengembangkan diri.

Berkenaan dengan butir (1) tentang penguasaan pendidik terhadap materi, struktur, konsep, dan pola pikir keilmuan yang mendukung mata pelajaran yang diampu oleh masing-masing pendidik, idealnya sudah menjadi bagian dari sosok pendidik profesional. Tetapi fenomena di lapangan, semua pihak harus jujur dan berlapang dada untuk menerima faktabahwa masih terdapat guru yang belum sepenuhnya memperlihatkan penguasaan sebagaimana mestinya.

Oleh karena itu, langkah yang diambil oleh kepala sekolah sudah tepat, dengan melakukan pembinaan secara intensif terhadap peningkatan profesionalisme pendidik khususnya dalam penguasaan materi, struktur, konsep, dan pola keilmuan yang mendukung mata pelajaran, karena hal tersebut sangat substansial dalam arti menjadi fondasi yang paling dasar bagi pelaksanaan tugas pendidik profesional. Halhal lain yang dianggap baik pada diri seorang pendidik profesional semuanya tidak akan bermakna manakala pendidik tersebut tidak memiliki kompetensi terhadap penguasaan materi pelajaran yang diampunya. 
Proposisi 3, Faktor pendukung dan penghambat.

a. Simpulan

Dari hasil proses analisis diperoleh simpulan bahwa dalam penerapan gaya kepemimpinan kepala sekolah kaitannya dengan peningkatan kinerja pendidik, baik internal maupun eksternal memiliki faktor pendukung dan penghambat. Faktor pendukung internal sebagian besar pendidik masih berusia muda yang produktif, pendukung eksternal banyaklembaga yang menyelenggarakan seminar, workshop, dan sejenisnya secara online. Faktor penghambat secara internal, kurangnya dana, kurangnya minat pendidik dalam mengembangkan diri secara mandiri, dan hambatan teknis.

\section{b. Analisis}

Berkenaan dengan dukungan dan hambatan dalam penerapan gaya kepemimpinan Kepala Sekolah kaitannya dengan peningkatan kinerja pendidik, Kepala sekolah memiliki dukungan dan menghadapi penghambat baik secara internal maupun eksternal. Secara internal, didukung oleh kondisi pendidik yang sebagian besar masih berusia muda dan secara eksternal didukung oleh banyaknya peluang untuk pengembangan diri bagi para pendidik, antara lain banyak lembagalembaga yang relevan penyelenggara seminar, workshop, dan sejenisnya secara online.

Di samping itu, secara internal penerapan gaya kepemimpinan Kepala SMK Negeri 1 Palasah terhambat oleh kondisi yang dilematis, antara lain anjuran pengembangan diri bagi pendidik dalam membuat modul atau bahan ajar sesuaimata pelajaran yang diampu. Tetapiterdapat buku paket yang disediakan pemerintah, sehingga dalam proses pembelajaran para pendidik banyak merujuk kepada sumber tersebut. Secara eksternal, sekolah belum memiliki akses kepada lembaga-lembaga luar yang relevan untuk pengembangan diri pendidik melalui akses kerjasama formal, misalnya kerjasamadengan perguruan tinggi, dengan penerbitbuku, dan sebagainya. Padahal, di era global seperti sekarang ini, keberadaan jaringan dan kerja sama sudah menjadi kebutuhan.

\section{c. Pembahasan}

Secara internal penerapan gaya kepemimpinan Kepala SMK Negeri 1 Palasah didukung oleh kondisi pendidik yang sebagian besar berusia muda yang masih produktif dan idealis. Dianggap sebagai pendukung karena memang keberadaan pendidik sangat besar perannyadalam suatu lembaga pendidikan, apalagi masih berusia muda yang produktif. Hal ini diakui oleh Kepala Sekolah, bahwa keberadaan pendidik yang berusia muda banyak membantu, karena cara berpikirlebih kritis dan idealis, responnya cepat. mobilitas tinggi dan memiliki ekspektasi ke masa depan yang sangat tinggi. Kondisi demikian memudahkan Kepala Sekolah dalam melaksanakan program peningkatan kinerja pendidik,

Secara eksternal, penerapan gaya kepemimpinan Kepala SMK Negeri 1 Palasah Kabupaten Majalengka didukung dengan banyaknya peluang untuk mengembangkan diri bagi para pendidik. Dengan adanya teknologi informasi yang semakin canggih, para pendidik dapat dengan mudah menerima informasi tentang lembagalembaga yang mengadakan kegiatan seminar, workshop, lokakarya dan sejenisnya.

Secara internal, terdapat faktor penghambat terhadap penerapan gaya kepemimpinan Kepala SMK Negeri 1 Palasah, yang sangat dirasakan saat ini adalah kurangnya biaya dan situasi pandemicovid19 yang berakibat pada banyaknya pembatasan aktivitas para pendidik dan situasi yang terus berubah sehingga menyulitkan untuk membuat perencanaan program baru, terutama dalam penetapan waktu dan tempat kegiatan. Akibatnya minat pendidik untuk mengembangkan diri secara mandiri menjadi kurang. Hal lain, guru dituntut untuk mengembangkan bahan ajar dengan cara membuat modul dan sejenisnya yang merupakan peluang untuk mengembangkan diri melalui karya inovatif. Tetapi dalam prakteknya guru lebih banyak merujuk pada buku paket yang sudah tersedia. Dalam hal pengembangan diri melalui penguasaan teknologi informasi, pendidik dan peserta didik terkendalasarana dan fasilitas pendukung lainnya. 
Idealnya, di sekolah telah tersedia jaringan internet/Wifi yang kuat, tetapi berkaitan dengan biaya rutin yang harus dikeluarkan.

Secara eksternal, penerapan gaya kepemimpinan kepala sekolah memiliki hambatan dalam membangun komunikasi dengan lembaga-lembaga yang relevan. Antara lain belum memiliki kerjasama antar lembaga, dengan perguruan tinggi, penerbit buku, lembaga-lembaga kursus dan sebagainya. Sedangkan kerjasama yang telah terbangun baru sebatas kerjasama dengan Dunia Usaha dan Dunia Industri (DUDI) dalam pelaksanaan praktek kerja industri untuk para peserta didik. Dalamhal ini, terkait dengan pengembangan keprofesionalan berkelanjutan dalam beberapa hal memerlukan aktivitas nyata di lapangan, tetapi saat ini kondisi pandemi yang membatasi interaksi dengan dunia luar terdapat keterbatasan.

Porposisi 4, Upaya kepala sekolah dalam mengatasi hambatan.

a. Simpulan

Dari hasil proses analisis diperoleh simpulan bahwa kepala sekolah telah melakukan berbagai upaya dalam mengatasi hambatan penerapan gaya kepemimpinan dengan baik. Upaya nyata yang telah dilakukan antara lain mengatasi kurangnya dana melalui musyaswarah dengan warga sekolah dan Pengurus Komite Sekolah, mengatasi hambatan rendahnya minat pendidik terhadap publikasi ilmiah dengan cara melakukan workshop serta kerjasama dengan penerbit buku dan para pakar, untuk mengatasi hambatan-hambatan teknis dilakukan melalui bermusyawarah dan berkoordinasi dengan Wakil KepalaSekolah terkait, dan Kepala tata Usaha, bahkan dengan Pengurus OSIS. Untuk mengatasi hambatan eksternal, Kepala Sekolah telah menjajagi menjalin kerjasama dengan Perguruan Tinggi, Penerbut Jurnal, Penerbit Buku, dan lembaga lain yang relevan.

\section{b. Analisis}

Dengan memperhatikan kesimpulan tersebut, kepala sekolah telah berupaya dengan baik. Keterbatasan dana, memang selalui dihadapi oleh sekolah-sekolah lain, termasuk SMK Negeri 1 Palasah. Hal ini bukan disebabkan karena lemahnya perencanaan anggaran, melainkan karena biaya ini merupakan unsur yang fleksibel dan selalu dihadapkan kepada perubahan, terutama dinamika ekonomi yang sangat berpengaruh terhadap anggaran sekolah. Namun demikian, kepala sekolah seakan sudah terbiasa menghadapi masalah ini, sehingga dihadapi dengan serius tanpa keluhan. Satu-satunya cara yang paling logis adalah menghadapi kenyataan dengan berbesar hati, maka upaya yang dilakukan dengan cara mengadakan musyaswarah bersama warga sekolah dan Pengurus Komite Sekolah merupakan cara paling mungkin. Bersama warga sekolah, substansinya menyepakati pelaksanaan program sesuai dengan anggaran yang ada, menunda program yang bukan program prioritas, meminta kesediaan pihak yang terlibat agar tidak terlalu berfokus kepada biaya, terutama berkaitan dengan honor, uang saku, atau fasilitas lainnya diusahakan menggunakan yang sekiranya terjangkau dengan anggaran yang tersedia.

Berkenaan dengan hambatan dalam bentuk rendahnya minat pendidik terhadap penulisan dan publikasi ilmiah, dilakukan dengan cara yang logis. Dalam arti, memotivasi para pendidik dengan menjelaskan bahwa menulis dan mempublikasikan karya ilmiah merupakan bagian yang tak terpisah kan dengan kehidupan dan karir pendidik profesional serta erat kaitannya dengan penilaan kinerja guru (PKG) yang akan dikaitkan dengan penetapan angka kredit sebagai syarat untuk kenaikan pangkat ke tingkat yang lebih tinggi. Dengan demikian penulisan dan publikasi ilmiah mutlak harus dijalani oleh pendidik apa pun alasannya. Setelah pendidik termotivasi, kepala sekolah melakukan tindakan operasional praktis dengan mengadakan program workshop bertujuan untuk meningkatkanpengetahuan, pemahaman, wawasan, dan keterampilan pendidik dalam menulis dan mempublikasikan karya ilmiah, baik melalui seminar lokal, menjadi nara sumber pada forum kegiatan ilmiah, atau publikasi melalui media massa dan jurnal ilmiah. Dalam hal hambatan teknis, misalnya pada 
saat akan dilaksanakan workshop menghadapi kesulitan menentukan waktu dan tempat yang tidak menganggu hari efektif dalam pembelajaran, cara memecahkan masalah tersebut Kepala Sekolah sudah terbiasa melakukan musyawarah dengan pihak terkait. Misalnya dengan wakil kepala sekolah, kepala tata usaha dan Pengurus OSIS, bahkan untuk halhal tertentu berkoordinasi juga dengan pengurus Komite Sekolah. Secara eksternal, hambatan yang dihadapi kurangnya akses terhadap lembaga-lembaga lain yang relevan kepala sekolah menjajagi untuk menjalin kerjasama dengan Perguruan Tinggi, Penerbit Jurnal, Penerbit Buku, dan lembaga lain yang relevan diharapkan dapat membuka akses atau mempermudah komunikasi untuk hal-hal yang relevan dengan pengembangan diri para pendidik.

c. Pembahasan

Berdasarkan hasil analisis data diperoleh informasi kepala sekolah telah berusaha mengatasi hambatan sesuai dengan jenis hambatan yang dihadapi. a) Masalah kurangnya dana, dalam beberapa hal masih menjadi kendala utama karena keterbatasan yang disebabkan karena berbagai faktor, salah satunya karena dari waktu ke waktu kondisi sosial-ekonomi yang selalu berubah yang berdampak pada harga-harga yang kurang stabil, sedangkan kebutuhan biaya tidak dapat dihindari karena berkaitan dengan program yang harus direalisasikan. Upaya kepala sekolah dilakukan dengan cara bermusyawarah dengan pihak terkait lalu berkoordinasi juga dengan Pengurus Komite Sekolah untuk melakukan re-planning,.

Cara lain yang ditempuh adalah mencari bantuan dari para donatur, terutama kepada pihak yang memiliki kepedulian terhadap pendidikan, baik perusahaan yang menjadi mitra sekolah seperti penerbit, perusahaan otomotif, dan perusahaan yang ada di sekitar lingkungan sekolah maupun perorangan; b) Masalah rendahnya minat pendidik dalam mengembangkan diri, bidang penulisan karya tulis ilmiah (KTI) dan Publikasi, kepala sekolah berusaha meningkatkan minat pendidik untuk terus berusaha agar aktif dalam publikasi ilmiah melalui berbagai cara. Antara lain secara berkala melakukan workshop tentang Penelitian Tindakan Kelas (PTK) dilanjutkan kepada teknis penulisan artikel ilmiah. Melakukan juga konsultasi cara menulis modul atau materi ajar sesuai dengan mata pelajaran masing-masing, bekerjasama dengan penerbit buku, dan mendorong pendidik untuk berani dan memulai menjadi nara sumber dalam kegiatan ilmiah baik di lingkungan sekolah maupun di lingkungan masyarakat atau lembaga-lembaga tertentu; c) Masalah teknis, antara lain berkaitan dengan waktu pelaksanaan lokakarya atau workshop yang sulit mencari titik temu di antara berbagai kesibukan individu. Dalam hal ini kepala sekolah memberikan wewenang kepada Wakil Kepala Sekolah Bidang Kurikulum dan Tata Usaha untuk bermusyawarah dengan perangkat $\mathrm{di}$ bawahnya. Bahkan, pengurus OSIS pun selalu dilibatkan dalam musyawarah ini. Dari beberapa kasus, hambatan dapat diatasi melalui musyawarah untuk mupakat. Upaya seperti ini menggambarkan juga tentang indikator tipe kepemimpinan demokratis yang terbukti mampu mengatasi masalah teknis; d) Masalah kurang terbukanya akses ke lembaga lain. Kepala sekolah sudah menjajagi kemungkinan kerjasama dengan Perguruan Tinggi, dengan Penerbit Buku, dan lembagalembaga kursus yang relevan. Dengan cara ini, ke depan diharapkan dapat memperlancar pelaksanaan program pengembangan diri bagi pendidik baik dalam hal pengadaan pakar sebagai nara sumber maupun dalam kerjasama fasilitas publikasi karya ilmiah, baik jurnal maupun karya ilmiah lainnya.

Dengan demikian, semua program yang ada dalam lingkup manajemen sekolah di lingkungan SMK Negeri 1 Palasah Kabupaten Majalengka, telah dilaksanakan secara sistematis dan terus-menerus, dengan mendapat dukungan semua pihak terkait secara sadar dan bertanggungjawab Namun untuk mengetahui dampaknya terhadap peningkatan kinerja pendidik, masih perlu penelitian khusus secara cermat dan mendalam karena ketercapaian kinerja pendidik yang optimal dipengaruhi banyak faktor. 


\section{PENUTUP}

Dari penelitian tentang analisis gaya kepemimpinan kepala sekolah dalam meningkatkan kinerja pendidik SMK Negeri 1 Palasah, disimpulkan sebagai berikut.

1. Kepala sekolah dalam meningkatkan kinerja pendidik cenderung menggunakan gaya kepemimpinan coaching (melatih), dengan memperlihatkan indikator yang kuat pada pemberian arahan, bimbingan kepada pendidik dalam pelaksanaan tugas; Mengawasi secara ketat terhadap pelaksanaan tugas pendidik; Sering meminta masukan dari bawahan dalam proses pengambilan keputusan, dan responship terhadap gagasan yang dikemukakan bawahan dalam mendukung kemajuan sekolah.

2. Capaian kepala sekolah dalam meningkatkan kinerja sudah baik, ditandai dengan meningkatnya tingkat profesionalitas pendidik terutama kompetensi pedagogik dan kompetensi profesional;penguasaan terhadap materimateri pada mata pelajaran; kreativitas pendidik dalam mengembangkan model /metode pembelajaran; kesadaran terhadap tugas pokok dan fungsinya sebagai pendidik; dan meningkatnya minat untuk menulis karya ilmiah, berkaitan dengan penelitian tindakan kelas, menulis modul, dan menulis artikel ilmiah. Hanya dari segi publikasi masih harus ditingkatkan lagi.

3. Faktor pendukung dan penghambat yang dihadapi kepala sekolah secara internal sebagian besar pendidik berusia muda dan produktif. Secara eksternal didukung banyaknya peluang yang ditawarkan untuk pengembangan diri pendidik, antara lain penawaran seminar online (webinar), workshop penulisan artikel ilmiah untuk dipublikasikan via jurnal. Faktor penghambat internal terdiri atas keterbatasan dana dan rendahnya minat pendidik dalam menulis karya ilmiah, dan hambatan teknis. Secara eksternal, terbatasnya akses ke lembaga luar sekolah yang relevan untuk bekerjasama dalam pengembangan diri para pendidik secara berkelanjutan.

4. Dalam mengatasi hambatan Kepala Sekolah telah melakukan berbagai upaya dengan baik. Dilakukan dengan musyawarah bersama warga sekolah dan komite sekolah untuk melakukan replanning. Untuk mengatasi rendahnya minat pendidik dalam menulis karya ilmiah, dilakukan pemotivasian dikaitkan dengan kewajiban guru professional, penilaian kinerja guru, dan penetapan angka kredit yang akan dijadikan bahan pertimbangna dalam usulan kenaikan pangkat ke tingkat yang lebih tinggi serta mengadakan kegiatan seminar, pelatihan, dan workshop tentang penulisan dan publikasi karya ilmiah, Untuk mengatasi hambatan teknis, selalu bermusyawarah dengan warga sekolah. Dalam hal keterbatasan akses ke lembaga luar sekolah, dilakukan penjajagan untuk menjalin kerjasama dengan Perguruan Tinggi, Penerbit Buku, dan lembaga lain yang relevan.

\section{DAFTAR PUSTAKA}

Amelia, Nova (2014) KontribusiPelaksanaan Pengawasan Terhadap Kinerja Pegawai pada Dinas Pendidikan Kota Sawahlunto, 2(1), 475-483.

Mangkunegara, AAP (2007). Manajemen Sumber Daya Manusia Perusahaan, Bandung: Rosda Karya.

Miles \& Huberman (1992) Analisis Data Kualitatif, Jakarta: Universitas Indonesia.

Moleong, Lexy, J. (2005) Metodologi Penelitian Kualitatif, Bandung. RemajaRosda Karya.

Murphy, K.R \& Davidshofer, C.O (2002). Psychological Testing, Principles and Applications sixth Edition, New Jersey: Pearson Education International.

Pidarta, Made (2006). Manajemen Pendidikan Indonesia, Jakarta: Rineka Cipta.

Priangani, Ade (2013) Memperkuat Manajemen Pemasaran dalamKonteks Persaingan Global, 2(4), 1-9.

Permendiknas No 13 Tahun 2007 tentang Standar Kepala Sekolah.

Permendiknas No 16 Tahun 2007 tentang Standar Kualifikasi Akademik dan Kompetensi Guru. 
Permadi Dadi. (2013). Kepemimpinan Transformasional Kepala Sekolah, Bandung: Sarana Panca Karya.

Robbins, Stephen P. and Coulter Mary. (2010). Manajemen Jilid 2, alih Bahasa Bob Sabran dan Devri Barnadi Putera, Jakarta: Penerbit Erlangga.

Suhartini, Eka (2014). Pengaruh Kompetensi terhadap Kinerja Pegawai, 17(1),6178.

Syamsudin, Sadili (2006) Manajemen Sumber Daya Manusia. Bandung: Pustaka Setia.

Ulya, Wildatun (2019) Peran Kepala Sekolah dalam Meningkatkan Mutu Pendidikan, 8(2), 1-7.

Undang-Undang Nomor 20 Tahun 2003 tentang Sistem Pendidikan Nasional.
Undang-undang Nomor 14 Tahun 2005 tentang Guru dan Dosen.

Nurdiansyah dan Rudiansyah (2015) Pengaruh Kinerja Pegawai terhadap Peningkatan Pelayanan di Perusahaan Daerah Air Minum, 6(1), 01-10.

Widodo (2005) Pengaruh antara Lingkungan Kerja dan Kepuasan Kerja, Surakarta:USU Lubrary.

Yaqin, Husnul. (2011). Kapita Selekta Administrasi dan Manajemen Pendidikan, Banjarmasin: Antasari Press.

\section{BIOGRAFI PENULIS}

Cucu Sunarti, SMK Negeri 1 Palasah, Kabupaten Majalengka, Provinsi Jawa Barat,
Indonesia.
email: nocusun74@gmail.com

